\title{
Drug-conjugated antibodies for the treatment of cancer
}

\section{John M. Lambert}

ImmunoGen, Inc, 830 Winter Street, Waltham, MA 02451, USA

\section{Correspondence}

Dr John M. Lambert PhD, ImmunoGen, Inc, 830 Winter Street, Waltham, MA 02451,

USA.

Tel.: +1 7818950600

Fax: +1 7818950613

E-mail: john.lambert@immunogen.com

\section{Keywords}

antibody-drug conjugates, brentuximab vedotin, lorvotuzumab mertansine, maytansine (maytansinoids), SAR3419, trastuzumab emtansine

\section{Received \\ 9 August 2012 \\ Accepted \\ 25 October 2012 \\ Accepted Article \\ Published Online \\ 23 November 2012}

\begin{abstract}
Despite considerable effort, application of monoclonal antibody technology has had only modest success in improving treatment outcomes in patients with solid tumours. Enhancing the cancer cell-killing activity of antibodies through conjugation to highly potent cytotoxic 'payloads' to create antibody-drug conjuates (ADCs) offers a strategy for developing anti-cancer drugs of great promise. Early ADCs exhibited side-effect profiles similar to those of 'classical' chemotherapeutic agents and their performance in clinical trials in cancer patients was generally poor. However, the recent clinical development of ADCs that have highly potent tubulin-acting agents as their payloads have profoundly changed the outlook for ADC technology. Twenty-five such ADCs are in clinical development and one, brentuximab vedotin, was approved by the FDA in August, 2011, for the treatment of patients with Hodgkin's lymphoma and patients with anaplastic large cell lymphoma, based on a high rate of durable responses in single arm phase II clinical trials. More recently, a second ADC, trastuzumab emtansine, has shown excellent anti-tumour activity with the presentation of results of a 991-patient randomized phase III trial in patients with HER2-positive metastatic breast cancer. Treatment with this ADC (single agent) resulted in a significantly improved progression-free survival of 9.6 months compared with 6.4 months for lapatinib plus capecitabine in the comparator arm and significantly prolonged overall survival. Besides demonstrating excellent efficacy, these ADCs were remarkably well tolerated. Thus these, and other ADCs in development, promise to achieve the long sought goal of ADC technology, that is, of having compounds with high anti-tumour activity at doses where adverse effects are generally mild.
\end{abstract}

\section{Introduction}

Oncologists viewed monoclonal antibody technology with great optimism when the technology was first developed [1], and then applied it to the generation of antibodies that bound to a variety of tumour-associated antigens [2]. Antibodies offered the promise of targeted elimination of tumour cells without the systemic toxicity associated with chemotherapy. Rituximab, which binds to CD20 expressed by $B$ cells and $B$ cell lymphomas, fulfills this promise $[3,4]$. It has excellent single-agent activity and has become the backbone of treatment of non-Hodgkin's lymphoma $(\mathrm{NHL})$. However, over three decades of clinical research with many antibodies to many cancer cell surface targets has resulted in just two targets on solid tumours to which there are antibodies approved for therapy, namely HER2 and EGFR $[5,6]$. In general, the immunological mechanisms for cell elimination induced upon antibody binding to cell surfaces have not proven effective against solid tumours without some mechanism for enhanced potency [7].

One approach to enhancing the cell-killing activity of antibodies that bind to cell surface targets on tumour cells is arming them with a cytotoxic effector agent to create compounds known as antibody-drug conjugates (ADCs). The early developments in the field of antibody-mediated delivery of cytotoxic agents to cancer cells were not successful due, in part, to the fact that the potency of the cytotoxic payloads used for the early ADCs was insufficient [8-10]. Recently, with the exciting clinical results now emerging with ADCs employing highly potent cytotoxic agents designed for antibody-mediated delivery, the promise of the ADC field has been reinvigorated [11-13]. In this review, the compounds of this burgeoning field that are in development will be summarized, and the clinical results for the most advanced ADCs (in phase II or III clinical trials), whose chemical structures are shown in Figure $1 \mathrm{~A}$ to 

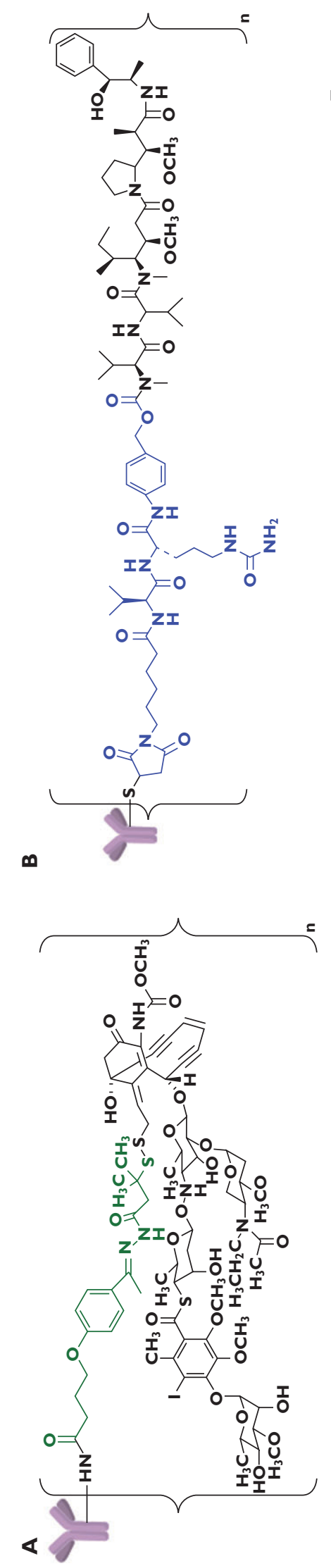

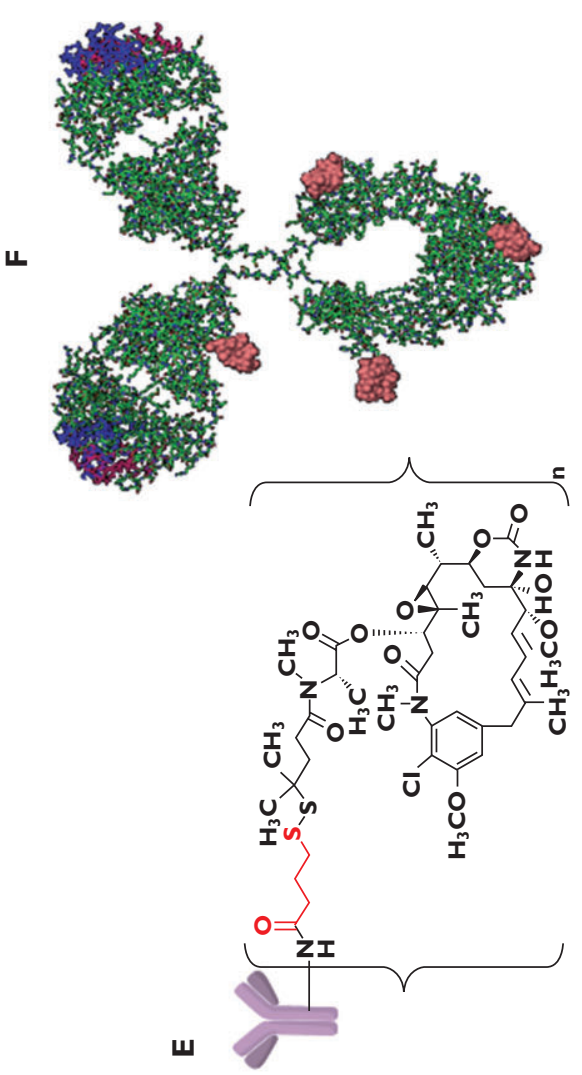

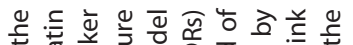

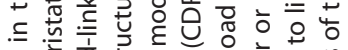

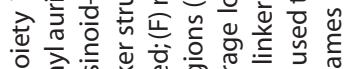

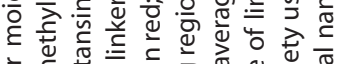

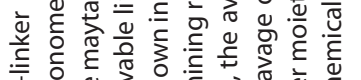

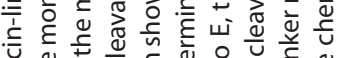

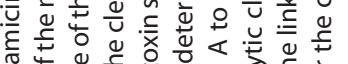

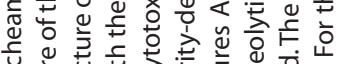

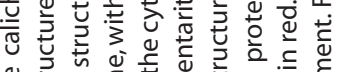

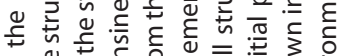

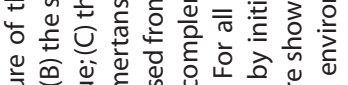

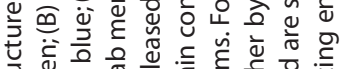

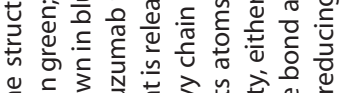

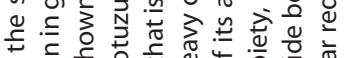

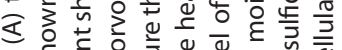

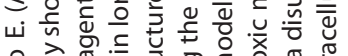

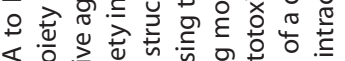

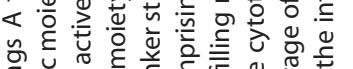

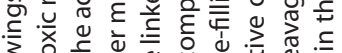

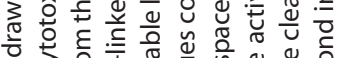

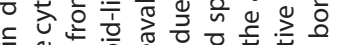

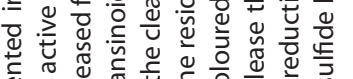

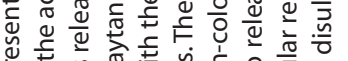

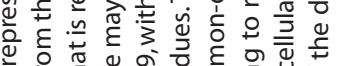
Q

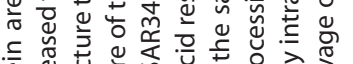

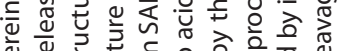

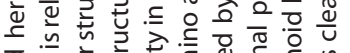
ठ

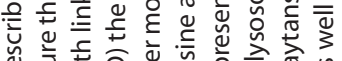

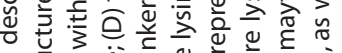

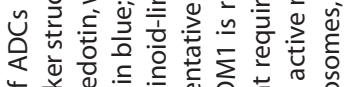

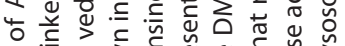

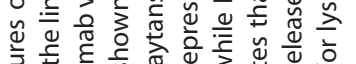

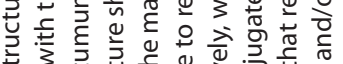

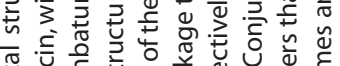
তั

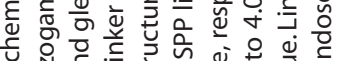

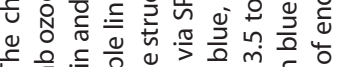

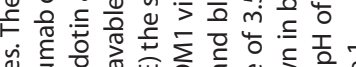

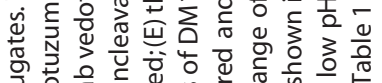

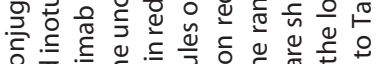

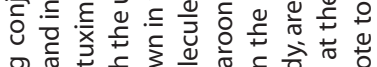
옹ㄷำ

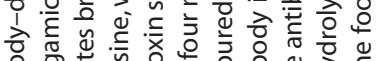

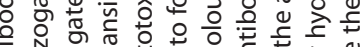

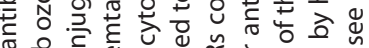

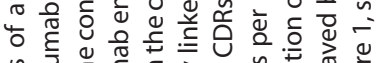

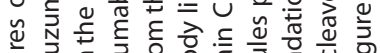

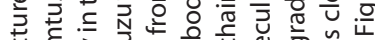
(1)

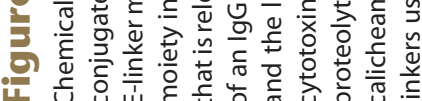


$\mathrm{E}$, will be described in more detail. Figure $1 \mathrm{~F}$ also shows a model of one such conjugate bearing four molecules of maytansinoid, to illustrate the molecular scale of a $150 \mathrm{kDa}$ IgG antibody conjugated to a cytotoxin-linker moiety of molecular weight about $1 \mathrm{kDa}$.

\section{ADCs in clinical development}

\section{ADCs with potent DNA-acting payloads}

The ADCs in clinical evaluation at the time of preparation of this review are listed in Table 1. Four of the 29 listed ADCs utilize DNA-targeting cytotoxic agents as their payload. Two of these compounds, gemtuzumab ozogamicin which targets CD33 expressed by cells of acute myeloid leukemia (AML), and inotuzumab ozogamicin which targets CD22 expressed on malignant B cells, are conjugates of humanized lgG4 antibodies with the highly potent DNA-alkylating agent, the enediyne antibiotic, calicheamicin [14, 15]. The payload is linked via an acid-labile hydrazide bond as well as a hindered disulfide bond (see Figure 1A for the chemical structure). Gemtuzumab ozogamicin was approved by the FDA in 2000 under an accelerated approval process for the treatment of relapsed $A M L$ in patients older than 60 years based on a response rate of about $30 \%$ in a single arm phase II trial in patients given $9 \mathrm{mg} \mathrm{m}^{-2}$ (about $0.24 \mathrm{mg} \mathrm{kg}^{-1}$ ) for two doses given 14 days apart $[16,17]$. However, a confirmatory post-approval phase III controlled trial (SWOG S0106) that was begun in 2004 of gemtuzumab ozogamicin combined with daunorubicin and cytosine arabinoside vs. the chemotherapy alone, was stopped early due to safety concerns coupled with no improvement in clinical benefit in the combination arm [18]. As a consequence, gemtuzumab ozogamicin was voluntarily withdrawn from the market in 2010 by the sponsor $[18,19]$. Subsequent findings in three additional randomized trials suggest that some AML patients may benefit from the addition of $A D C$ to chemotherapy [19-21], but to date, the compound remains off the market and its future development remains uncertain.

Inotuzumab ozogamicin is currently being evaluated in a phase III study in relapsed or refractory aggressive nonHodgkin's lymphoma (NHL) in combination with rituximab, as well as a number of single agent and combination studies in NHL and acute lymphoblastic leukemia (ALL) (http://clinicaltrials.gov). A phase III study in follicular NHL was terminated due to poor enrolment. A phase I study in non-Hodgkin lymphoma established $1.8 \mathrm{mg} \mathrm{m}^{-2}$ (about $0.05 \mathrm{mg} \mathrm{kg}^{-1}$ ) given every 4 weeks as the maximum tolerated dose (MTD) with thrombocytopenia, neutropenia and leucopenia the most common adverse events [15, 22]. Among the 49 patients who were treated at the MTD in this study, the objective response rate (ORR) was $41 \%$, with rates of $68 \%$ and $15 \%$ for follicular lymphoma (22 patients) and diffuse large $B$ cell lymphoma (DLBCL, 26 patients), respectively. At the MTD, $63.3 \%$ of patients had grade 3 or
4 thrombocytopenia and $34.7 \%$ had grade 3 or 4 neutropenia. A total of $24 \%$ of all patients in the trial discontinued treatment because of thrombocytopenia. Just one patient experience veno-occlusive disease in the phase I study [22], a toxicity of concern with gemtuzumab ozogamicin [23]. Such hepatic toxicity may be a concern when treatment with the ADC is followed by high dose chemotherapy coupled with autologous stem cell transplant [24]. Inotuzumab ozogamicin has been shown to be active in ALL, with an ORR of 57\% (18\% complete responses) in a 49 patient phase II trial [25].

An ADC utilizing another DNA agent as its effector moiety is MDX-1203, an anti-CD70 antibody to which is attached a prodrug form of a cytotoxic DNA minor-groove binder, an analogue of CC-1065 (rachelmycin), via a dipeptide linker [26].This conjugate is being evaluated in a phase I trial in patients with CD70-positive renal cell cancer and CD70-positive NHL [26]. Enrolment has been discontinued (http://clinicaltrials.gov), and reporting of results is eagerly awaited. The fourth ADC in Table 1 utilizing a DNA-acting agent is the CD74-targeting milatuzumab-doxorubicin conjugate in phase I development for multiple myeloma [27].

\section{ADCs in clinical development utilizing potent tubulin-acting agents}

Serious side effects with gemtuzumab ozogamicin included severe myelosuppression [22] and venoocclusive disease [23,24], among others, indicating that this ADC has a side effect profile similar in nature to that of non-targeted chemotherapy regimens. However, during the last decade, the clinical development of ADCs that have highly potent tubulin-acting agents as their payloads has profoundly changed the outlook for ADC therapeutics. Twenty-five of the 29 ADCs listed in Table 1 utilize one of two classes of potent tubulin-binding antimitotic agent, either maytansinoids or auristatins $[11,13]$. Both agents bind to the vinca-binding domain of tubulin and have similar cytotoxic potency in the picomolar range [28]. Auristatin conjugates are made by reducing native disulfide bonds within antibodies to generate cysteine sulfhydryl groups for subsequent reaction with maleimido derivatives of auristatins $[29,30]$, while maytansinoid conjugates are made by attaching thiol derivatives of maytansine to lysine amino groups of antibodies using a crosslinking reagent selected from a portfolio of such agents $[11,31]$. To date, ADCs in development utilizing either of these payloads generally have an average of about 3.5 to 4.0 molecules of the cytotoxic agent linked per antibody molecule [9-11], with most antibody molecules having a cytotoxin load between two to six drugs per antibody [11, 29, 31, 32].

The ADCs made with the potent tubulin-binding agents release active payload after internalization and processing within endosomes or lysosomes [30, 33, 34]. There are two designs of auristatin-linker being utilized in 


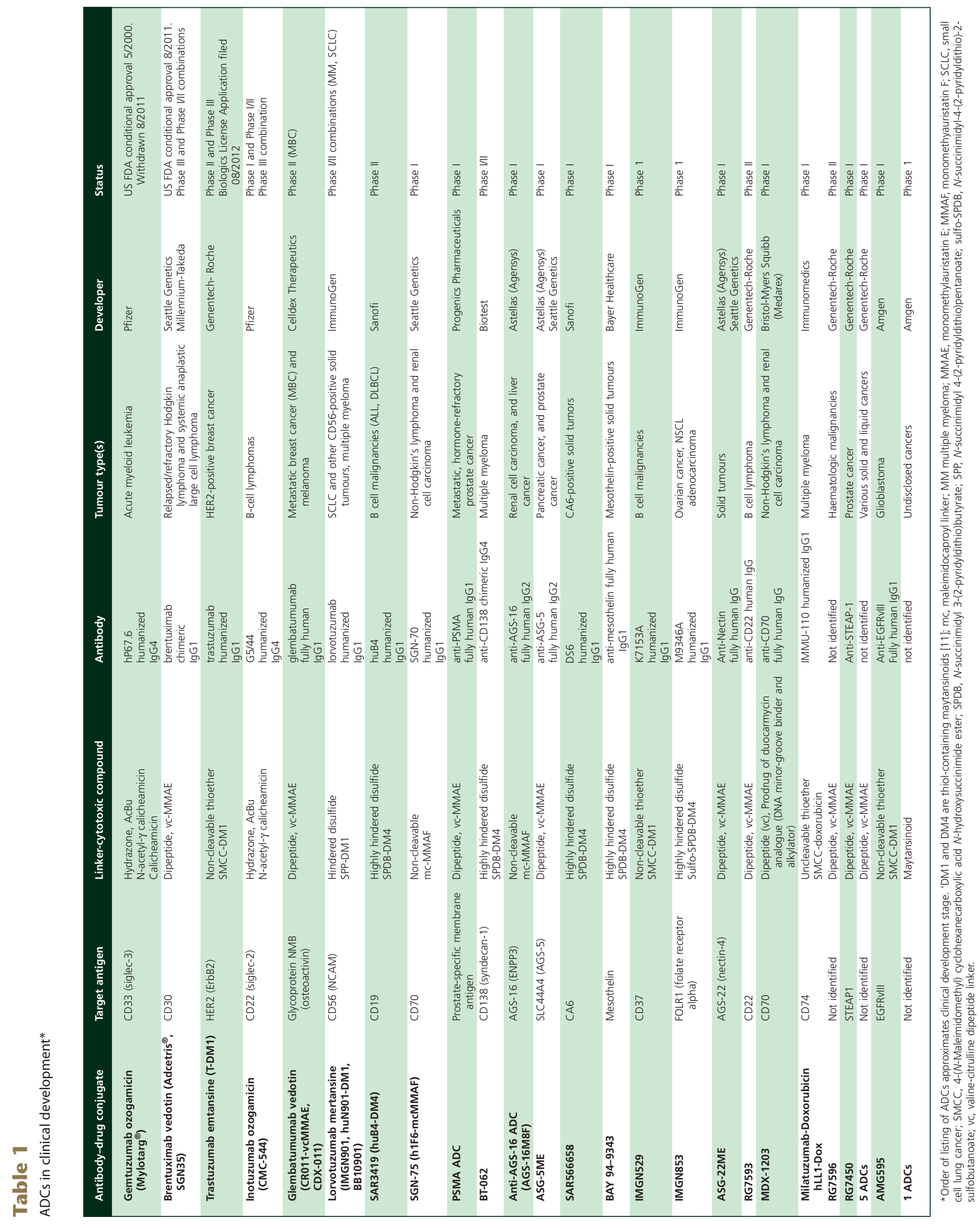


ADCs in current development (Table 1), and both require intracellular proteolysis to release active cytotoxic metabolites within the cell, either for cleavage of the linker to release the aurisatin, or for complete degradation of the antibody to release an auristatin-linker-cysteine moiety as the active species [30,31]. There are also two different maytansinoids being utilized with four different maytansinoid-linker designs for maytansinoid-conjugates in current development (Table 1). Intracellular release of active maytansinoid is either by complete proteolysis of the antibody moiety to yield an active maytansinoidlinker-lysine metabolite [11, 33, 34], or by reduction of a disulfide bond between the thiol derivative of maytansine and the crosslinker to release a thiol-containing maytansinoid [11, 33-35]. Selection of the linker-payload design with which to arm an antibody to a given target is empiric with an emphasis on in vivo assessment in xenograft tumour models to identify the design having the widest therapeutic window in such preclinical models [11, 31, 33-35]. Of the compounds listed in Table 1, the most advanced, brentuximab vedotin and trastuzumab emtansine, are attracting considerable attention for their efficacy and tolerability profile. These ADCs offer the promise of realizing the design goal of the technology, that is, of achieving highly active anti-tumour activity at doses where adverse effects are generally mild.

Brentuximab vedotin Brentuximab vedotin (BV, originally called SGN-35) is an anti-CD30 ADC made utilizing the auristatin MMAE (see Figure 1B), approximately four molecules of which are linked through a peptide linker to free sulfhydryl groups of cysteine residues of the chimeric lgG1 antibody formed by partial reduction of inter-chain disulfide bonds of the immunoglobulin $[29,30,36]$. BV was granted conditional approval under the acceleratedapproval process by the FDA in August 2011 for the treatment of two indications, patients with Hodgkin lymphoma $(\mathrm{HL})$ after failure of autologous stem cell transplant or those ineligible for transplant who have failed at least two chemotherapy regimens, and patients with systemic anaplastic large cell lymphoma (ALCL) after failure of multiagent chemotherapy. Approval for $\mathrm{HL}$ was based on a single arm phase II trial in which 102 patients received BV at $1.8 \mathrm{mg} \mathrm{kg}^{-1}$ every 3 weeks for up to 16 cycles [37]. Remarkably, tumour reductions were seen in $94 \%$ of enrolled patients on this trial. The ORR was $75 \%$ with a median progression-free survival for all patients of 5.6 months. Thirty-four percent of patients achieved complete remission (CR) having a median duration of 20.5 months [37]. Approval for ALCL was based on another single arm phase II trial in which 58 patients were also treated at $1.8 \mathrm{mg} \mathrm{kg}^{-1}$ every 3 weeks [38]. The ORR was $86 \%$ with a median duration of 12.6 months, while $57 \%$ of patients achieved a CR with a median duration of 13.2 months [38]. The most common adverse reactions of any grade noted in these trials were peripheral sensory neuropathy $(42 \%$ of patients), nausea (35\%), fatigue (34\%), neutropenia (19\%) and diarrhoea (18\%), seen in $\geq 15 \%$ of patients [37]. The neuropathy was consistent with a class effect of tubulinbinding cytotoxic agents, and typically developed after prolonged exposure to BV, with a median onset of grade 2 neuropathy at 27.3 weeks. It was largely reversible and could be managed by dose delays and/or dose reduction [37].

Besides these adverse events, the dose-limiting toxicities (DLTs) observed in the initial phase I clinical evaluation of $B V$ at doses of $2.7 \mathrm{mg} \mathrm{kg}^{-1}$ and $3.6 \mathrm{mg} \mathrm{kg}^{-1}$ every 3 weeks were febrile neutropenia, thrombocytopenia and hyperglycaemia [39]. A more frequent dosing regimen (weekly) was also evaluated in a phase I study. The results of this trial demonstrated a similar level of activity, with a similar adverse event profile [40]. In these phase I studies, the halflife of intact conjugate was estimated at 4 to 6 days.

Several clinical trials are under way or planned to evaluate further the activity and safety of BV. In particular, a confirmatory phase III trial in HL patients following autologous stem cell transplant is ongoing. In addition, several phase I and phase II trials are under way evaluating BV in combination with chemotherapy for front-line treatment of $\mathrm{HL}$, and as a single agent or as part of a combination regimen for treating $\mathrm{HL}$, and other $\mathrm{CD} 30$-positive malignancies [41], in a variety of disease and treatment settings (http://clinicaltrials.gov, and sponsor websites).

Trastuzumab emtansine Trastuzumab emtansine (T-DM1, also called trastuzumab-DM1) combines the humanized IgG1 anti-HER2 antibody, trastuzumab, with the maytansinoid DM1 utilizing an uncleavable crosslinking reagent, SMCC, to couple the thiol of DM1 (about 3.5 DM1 molecules per antibody) to surface amino groups of lysine residues of the antibody via a thioether bond (Figure 1C) [42]. The cytotoxic metabolite released within cancer cells is the DM1-linker-lysine moiety $[43,44]$. The particular conjugate design was selected for clinical development based on potent anti-proliferative activity in vitro and anti-tumour activity in vivo in preclinical models including HER2-overexpressing models resistant to trastuzumab [42]. A phase I clinical trial in patients with HER2positive metastatic breast cancer (MBC) that had progressed upon treatment with trastuzumab (mean of 24 months on trastuzumab before treatment failure) established an MTD of $3.6 \mathrm{mg} \mathrm{kg}^{-1}$, with the DLT at $4.8 \mathrm{mg} \mathrm{kg}^{-1}$ being reversible thrombocytopenia, when T-DM1 was administered once every 3 weeks [45]. Of 15 patients treated at $3.6 \mathrm{mg} \mathrm{kg}^{-1}$, the clinical benefit rate (CBR) was $73 \%$ (objective responses plus stable disease of $\geq 6$ months), and the confirmed ORR in patients with measurable disease $(n=9)$ was $44 \%$, an exciting signal of activity in a phase I trial. The median duration of treatment for these 15 patients was 238 days [45]. An MTD of $2.4 \mathrm{mg} \mathrm{kg}^{-1}$ was established when weekly administration was assessed, equating to double the dose intensity of 
every 3 week dosing, and a similar level of activity was observed in this small study [46].

A proof of concept phase II trial was then conducted evaluating T-DM1, used alone, administered at $3.6 \mathrm{mg} \mathrm{kg}^{-1}$ every 3 weeks in 112 patients with HER2-positive MBC [47]. All patients had received prior trastuzumab therapy, median duration of 17.6 months (range 1-152 months), as one of their prior systemic anticancer treatments (median of five prior agents for treatment of their MBC). According to independent review, this trial demonstrated an ORR of $25.9 \%$, while $49.1 \%$ of patients were assessed as having stable disease for a $75 \%$ CBR [47]. T-DM1 was well tolerated, with no dose-limiting cardiotoxicity and 21 patients completed at least 1 year of treatment on study. The most common adverse events were fatigue, nausea and headache (grade 1 or 2). Grade 3 and 4 toxicities were infrequent, the most common being hypokalaemia (8.9\%), thrombocytopenia (8.0\%) and fatigue (4.5\%). These findings were confirmed and extended in a second phase II trial that enrolled 110 patients with HER2-positive MBC who all had previously received a taxane, an anthracycline, capecitabine, lapatinib and trastuzumab, and who had progressed on their last regimen [48]. Importantly, the prior therapies for MBC included two HER2-directed regimens (lapatinib for a median duration of treatment of 6.9 months and trastuzumab for a median duration of treatment of 19.4 months). In these heavily pre-treated patients, the confirmed ORR was $33 \%$ with a CBR of $44 \%$, as assessed by independent review, with a median progression-free survival (PFS) of 6.9 months [48]. Among patients with retrospective central confirmation of HER2-positive status ( $n=77$, about $83.5 \%$ of those tested), the ORR rose to $40 \%$ and the median PFS to 8.0 months. There were no new safety signals, with the most common adverse events being fatigue $(62 \%)$, nausea $(37 \%)$ and thrombocytopenia $(33 \%)$, mostly grade 1 or 2 . Indeed, the authors noted that the absence of significant toxicity was noteworthy given the extensive pretreatment of the patients [48].

The combined data from 288 patients who received $3.6 \mathrm{mg} \mathrm{kg}^{-1}$ of T-DM1 every 3 weeks in the phase I and II trials were used to determine the pharmacokinetic parameters of T-DM1 [49]. Clearance is best described by a two compartment linear model with a half-life of approximately 4 days and a volume of distribution limited to the plasma volume. In the phase I dose escalation study, the half-life was dose-dependent with faster clearance at or below $1.2 \mathrm{mg} \mathrm{kg}^{-1}$, suggesting that antigen-mediated disposition plays a significant role in T-DM1 clearance [45]. This is consistent with recent data generated utilizing immuno-PET imaging with 89Zr-trastuzumab [50]. The concentration of non-conjugated DM1 was very low, with its maximum concentration having an average value of only about $5 \mathrm{ng} \mathrm{ml}^{-1}$, compared with an average $C_{\max }$ for T-DM1 of about 75 to $80 \mu \mathrm{g} \mathrm{ml}^{-1}$ [49], equivalent to about $1.5 \mu \mathrm{g} \mathrm{ml}^{-1}$ of conjugated DM1 [42]. Even this very low amount of free DM1 (about $0.3 \%$ of total bound DM1) may have been the consequence of cleavage during ex vivo sample handling [51]. The immunogenicity of T-DM1 in these studies was reported to be low, with just 13 of 286 patients (4.5\%) testing positive for anti-product antibodies which had no impact on T-DM1 pharmacokinetics [49].

The results of a randomized phase II trial in HER2positive breast cancer patients previously untreated for metastatic disease show that treatment with T-DM1 provided a significant improvement in PFS, from 9.2 months with standard-of-care trastuzumab plus docetaxel $(n=70$ patients), to 14.2 months with T-DM1 ( $n=67$ patients), with a similar ORR in the two arms, $58 \%$ for trastuzumab plus docetaxel compared with $64 \%$ in the T-DM1 arm [52]. The evidence for impressive single agent activity for T-DM1 was coupled with a favourable safety profile in this first line patient population. Adverse events that were $\geq$ grade 3 were reported at about half the rate in the T-DM1 arm $(46.4 \%$ vs. $89.4 \%)$, with no new safety signals, and no clinically significant cardiac events $[52,53]$.

T-DM1 is being evaluated for treatment of MBC in three randomized phase III trials (http://clinicaltrials.gov, and sponsor web sites), in first line treatment of MBC (trial name MARIANNE), after treatment with trastuzumab and a taxane in any setting (trial name EMILIA) and as third line treatment (trial name TH3RESA). The sponsor filed a marketing application with the FDA in August, 2012, based on the results of the 991-patient EMILIA trial, initial data for which were presented at the 2012 annual meeting of the American Society of Clinical Oncology [54]. Treatment with T-DM1 significantly prolonged PFS compared with treatment with lapatinib plus capecitabine in the comparator arm, 9.6 months vs. 6.4 months, respectively. Median overall survival was 30.9 months in patients treated on the T-DM1 arm, significantly longer than the 25.1 months achieved by the comparator arm [54]. The ORR was higher with single agent T-DM1 at $43.6 \%$ vs. $30.8 \%$ in the comparator arm. Not only did the efficacy end points favour the T-DM1 arm, fewer T-DM1-treated patients experienced grade 3 or higher adverse events than those treated on the comparator arm $(40.8 \%$ vs. $57 \%$, respectively) and there were no new safety signals in the study [54]. The robust anti-tumour activity and excellent tolerability exhibited by T-DM1 in the phase I, II and III trials suggest that this exciting new agent may change the treatment paradigm for HER2-positive MBC, as well as other HER2-positive cancers $[55,56]$. Besides development in breast cancer, a phase II/III clinical trial was recently begun to evaluate the potential for T-DM1 to improve treatment outcomes in patients with HER2-positive gastric cancer. (http://clinicaltrials.gov).

Glembatumumab vedotin Glembatumumab vedotin (GV, CDX-011, previously CR011-vcMMAE) combines an antiGPNMB fully human IgG2 antibody with the peptidelinked auristatin, vCMMAE [57], the same linker-payload format as used in BV (see Figure 1B). The target, GPNMB, also known as osteoactivin, is a type 1 transmembrane 
glycoprotein that is strongly expressed in melanoma and breast cancer [57, 58]. GV is highly active in preclinical xenograft models of melanoma [57]. Two phase I/II trials were conducted in patients with advanced metastatic cancers, one in patients with melanoma [59], and the second in patients with breast cancer [60]. In both studies, the MTD was $1.88 \mathrm{mg} \mathrm{kg}^{-1}$ administered once every 3 weeks.

In the phase $1 / I$ study conducted in patients with melanoma [59], a total of 117 patients were treated with a variety of doses and schedules. Antitumour activity was reported, with five objective responses (14\%) noted in the phase II expansion cohort in patients treated at the MTD on the 3 week schedule ( $n=36$ patients). Treatmentrelated severe adverse events (grade 3 or 4 ) occurring in $>10 \%$ of patients treated at $1.88 \mathrm{mg} \mathrm{kg}^{-1}$ every 3 weeks (a total of 43 patients) were rash ( $26 \%$ of patients) and neutropenia ( $14 \%$ of patients). The most frequent treatmentrelated adverse events of any grade at this dose schedule included rash (70\%) fatigue (65\%), alopecia (63\%), pruritis $(63 \%)$, diarrhoea $(47 \%)$ and neuropathy $(35 \%)$. There was evidence of increased activity with more frequent dosing (weekly or 2 weekly doses every 3 weeks), but this was accompanied by increased toxicity, notably the incidence of grade 3 or 4 neuropathy increased from $5 \%$ at the MTD on the every 3 week schedule ( $n=43$ patients) to $27 \%$ at the MTD $\left(1 \mathrm{mg} \mathrm{kg}^{-1}\right)$ of weekly dosing ( $n=15$ patients), which led to the selection of $1.88 \mathrm{mg} \mathrm{kg}^{-1}$ every 3 weeks dose schedule for the phase II expansion [59]. Dosedependent pharmacokinetics were observed, the half-life of the conjugate increasing with increasing dose on the once every 3 week schedule, from $16 \mathrm{~h}$ up to $38 \mathrm{~h}$ during dose escalation, providing evidence of a saturable target antigen-mediated disposition [59].

The finding that GPNMB was expressed on the tumour and/or stroma of $>40 \%$ of breast cancer samples, and that high expression in triple negative breast cancers was associated with increased risk of recurrence of disease [58], provided the rationale for the second phase I/II study conducted in 42 breast cancer patients [60]. Only two patients (6\%) had confirmed partial responses from 34 patients who received the MTD dose of $1.88 \mathrm{mg} \mathrm{kg}^{-1}$ every 3 weeks, although patients were not pre-selected for GPNMB expression in this study. Immunohistochemical analysis done on tumour samples obtained during the study showed significant GPNMB expression on stroma and/or tumour cells in nine of 14 cases examined (64\%). The two patients with a partial response (PR) were both GPNMBpositive, and continued on treatment for 27 and 54+ weeks [60]. The most frequent treatment-related adverse events of any grade across all doses, $1.0 \mathrm{mg} \mathrm{kg}^{-1} \quad(n=3)$, $1.34 \mathrm{mg} \mathrm{kg}^{-1}(n=5)$ and $1.88 \mathrm{mg} \mathrm{kg}^{-1}(n=34)$, included fatigue $(50 \%)$, rash $(48 \%)$, nausea $(40 \%)$, neuropathy $(38 \%)$, alopecia (33\%), neutropenia (31\%) and vomiting (31\%). Of these, the only severe adverse events (grade 3 or 4 ) occurring in $>10 \%$ of patients were neutropenia $(21 \%$ of patients). On the basis of these findings, a randomized phase II trial in patients with advanced, GPNMB-expressing, heavily pre-treated breast cancer is ongoing (http:// clinicaltrials.gov), comparing treatment with single agent GV vs. single agent chemotherapy (investigators' choice).

Lorvotuzumab mertansine Lorvotuzumab mertansine (LM, also known as IMGN901, and previously as BB-10901) comprises a humanized lgG1 version of the N901 antibody, lorvotuzumab [61, 62], conjugated at lysine residues to an average of about 3.7 DM1 molecules per antibody molecule via the SPP cross-linker that forms a hindered disulfide bond with the DM1 (Figure 1D) [32].The antibody targets the CD56 antigen, also called neuronal cell adhesion molecule, or NCAM $[61,63]$, which is expressed on a variety of cancers of haematopoietic and neuroendocrine origin, including multiple myeloma (MM) and certain leukemias and lymphomas [64,65], small cell lung cancer (SCLC) [66], ovarian cancer [67], carcinoid tumours and neuroblastoma [66]. LM has exhibited potent anti-tumour activity in a variety of preclinical xenograft models in these disease indications $[64,67,68]$. LM is being studied in both solid and haematopoietic tumours in clinical trials.

A phase I trial in CD56-positive solid tumours established $75 \mathrm{mg} \mathrm{m}^{-2}\left(\sim 2.0 \mathrm{mg} \mathrm{kg}^{-1}\right)$ as the MTD, when LM was administered daily for 3 consecutive days every 3 weeks, and established $60 \mathrm{mg} \mathrm{m}^{-2}$ as the recommended phase II dose on this schedule $[69,70]$. In MM, where $70-80 \%$ of patients have disease expressing CD56 [64], a phase I dose escalation trial established $112 \mathrm{mg} \mathrm{m}^{-2}\left(\sim 3.0 \mathrm{mg} \mathrm{kg}^{-1}\right)$ as the MTD when LM was administered weekly for 2 consecutive weeks on a 3 week cycle [71]. The half-life of LM was only about 1 to 1.5 days at doses $\geq 60 \mathrm{mg} \mathrm{m}^{-2}$ across all the phase I studies. This relatively short half-life is likely due to natural killer cells which express CD56 [61] serving as an antigen sink [72]. The DLTs in patients dosed at $140 \mathrm{mg} \mathrm{m}^{-2}$ in the MM trial were grade 3 fatigue in two of six patients and grade 3 acute renal failure in one of these patients [71]. Grade 3 toxicities of myalgia (one patient) and headache and back and shoulder pain (one patient) in two of two patients dosed at $94 \mathrm{mg} \mathrm{m}^{-2}$ given daily for 3 days on a 3 week cycle were the DLTs in the solid tumour trial $[69,70]$. In the first clinical trial conducted with $\mathrm{LM}$, assessing the compound given weekly for 4 weeks on a 6 week cycle in CD56-positive solid tumours, found dose-limiting headache at doses $\geq 60 \mathrm{mg} \mathrm{m}^{-2}$, having onset within about $8 \mathrm{~h}$ and largely resolved by about $48 \mathrm{~h}[72,73]$. Dose-limiting headache was not seen in later studies once routine low dose steroid prophylaxis was utilized prior to treatment [69-71]. The most common side effects were grade 1 or grade 2 headache, fatigue, nausea and neuropathy, each seen in about $30 \%$ of patients across all the phase I studies (193 total patients reported). The incidence of grade 3 peripheral neuropathy across the above three studies was only $2.5 \%$, with no reported grade 4 events [69-74]. There were no clinically significant changes in haematologic 
parameters with no evidence for clinically significant myelosuppression.

Encouraging evidence for antitumour activity was reported in the above three clinical studies of single agent LM. In the 37 patients with MM who were treated with LM at doses ranging from $40 \mathrm{mg} \mathrm{m}^{-2}$ to $140 \mathrm{mg} \mathrm{m}^{-2}$ (25 patients treated at $\geq 112 \mathrm{mg} \mathrm{m}^{-2}$ ), the overall CBR was $41 \%$, with three objective PRs, three objective minimal responses and 15 patients with stable disease for $\geq 3$ months $[71,75]$. In the two trials conducted in patients with CD56-positive solid tumours, there were two PRs (one unconfirmed) and 15 cases of clinically meaningful stable disease noted from the 68 patients with SCLC included in the 113 patients evaluated at the time of data cut-off of the most recent report $[69,70,73,74]$. From among 12 patients with Merkel cell carcinoma (MCC) from among the 45 evaluable patients on the trial evaluating the daily times three dosing schedule [70], there were two durable complete responses ( $2+$ years), and three patients with clinically meaningful stable disease (4 to 7+ cycles of treatment), notable observations in this rare, aggressive small cell cancer of the skin [76]. The findings of activity in MCC support the observations of activity in SCLC since these aggressive cancers are similar in cell morphology, in their near uniform expression of CD56, and in the dismal outcome of their clinical course [70, 74, 76, 77].

Based on these promising signals of clinical activity in these difficult to treat cancers, and on the preclinical results reporting improved antitumour activity of $L M$ in combination with chemotherapeutic regimens [68,78-80], and coupled with the acceptable tolerability profile of $L M$, in particular the lack of clinically meaningful myelosuppression [69-75], clinical studies of LM in combination with lenalidomide and low dose dexamethasone in MM [75, 81], and in combination with carboplatin and etoposide in SCLC (http://clinicaltrials.gov), have been initiated. The early experience reported with the LM plus lenalidomide/ dexamethasone combination in a single arm study demonstrated encouraging activity for this regimen $[75,81]$.LM is being assessed in combination with carboplatin/ etoposide for first line SCLC (extensive-stage disease) in a phase II trial which started in March 2012 (http:// clinicaltrials.gov), using an LM dose of $112 \mathrm{mg} \mathrm{m}^{-2}$ (two weekly doses on a 3 week cycle) established in an initial dose escalation phase [82]. Of 33 patients dosed in the phase I portion of the study, 13 were SCLC patients and six of these (46.2\%) had an objective response, including two of seven patients who were platinum resistant/refractory [82]. In the phase II assessment, previously untreated SCLC patients will be randomized 2:1 to receive either (i) up to six cycles of carboplatin/etoposide plus LM followed by maintenance LM or (ii) up to six cycles of the standard-ofcare chemotherapy doublet only.

SAR3419 (huB4-DM4) SAR3419 is an ADC comprising a humanized monoclonal lgG1 antibody (huB4) attached to
3.5 to 4 molecules of the maytansinoid DM4 through reaction of an optimized cleavable linker with lysine amino groups of the antibody (Figure 1), to form a hindered disulfide bond between the SPDB linker and DM4 [83-85]. SAR3419 shows superior anti-tumour activity to rituximab in preclinical xenograft models for $\mathrm{NHL}[86,87]$ and is now in phase II clinical evaluation.

The preliminary results from the first phase I trial of single dose administration every 3 weeks for up to six cycles found the MTD to be $160 \mathrm{mg} \mathrm{m}^{-2}\left(\sim 4.3 \mathrm{mg} \mathrm{kg}^{-1}\right)$, a dose level subsequently used to treat an expanded cohort of 20 patients $[88,89]$. Of the 35 response-evaluable patients at the time of initial reporting of the study, tumour shrinkage was reported in more than half the patients (74\%), with six objective responses [88]. Notably, seven of 15 patients with rituximab refractory disease showed tumour shrinkage, with one objective response. Tumour shrinkage was seen in a variety of lymphoma subtypes including DLBCL, follicular lymphoma and marginal zone lymphoma [89]. The DLT at doses $>200 \mathrm{mg} \mathrm{m}^{-2}$ was reversible toxicity to the cornea that did not preclude continued dosing with dose delays of 1-2 weeks at $208 \mathrm{mg} \mathrm{m}^{-2}$, with no other clinically significant grade 3 or 4 toxicities reported $[88,89]$. As with other maytansinoid $A D C s$, there was no clinically significant myelosuppression $(n=38$ patients), suggesting that SAR3419 may be readily combined with conventional chemotherapy regimens. The half-life of SAR3419 in these patients appeared to be 4-6 days across all doses of the phase I trial [89]. These early results demonstrated promising activity and tolerability, especially considering the wide dose range $\left(10 \mathrm{mg} \mathrm{m}^{-2}-\right.$ $270 \mathrm{mg} \mathrm{m}^{-2}$ ), the heavy pre-treatment of these patients ( $24 \%$ had prior stem cell transplant), and the mixed histology of those enrolled in the phase I trial.

A second study with a schedule of weekly dosing for 8 weeks, with the possibility of a further four cycles if sought, established an MTD of $55 \mathrm{mg} \mathrm{m}^{-2}$ (about $1.5 \mathrm{mg} \mathrm{kg}^{-1}$ week $^{-1}$ ) [90]. The dose intensity reached was similar to that of the 3 week dosing schedule. A total of 44 patients received doses ranging from $10 \mathrm{mg} \mathrm{m}^{-2}$ to $70 \mathrm{mg} \mathrm{m}^{-2}$ per week, with 21 patients treated at the MTD. Of 38 patients receiving doses of $\geq 20 \mathrm{mg} \mathrm{m}^{-2}$ per week, 12 (32\%) achieved an objective response including six with $\mathrm{CR} / \mathrm{CR}$ unconfirmed. Responses were seen in a variety of lymphoma sub-types (follicular lymphoma, DLBCL and Mantle cell lymphoma). SAR3419 was well tolerated on this dosing schedule, with a median number of doses delivered per patient of eight overall, and a median relative dose intensity of 0.96 at the MTD, with the investigators commenting on the noteworthy lack of clinically significant myelosuppression [90]. While reversible ocular toxicity was noted on this dosing regimen, it was with a late onset (mainly post cycle 7 or 8 ) and the incidence and severity of the observations was markedly reduced relative to the 3 week schedule $[88,90]$. The half-life for the plasma clearance of SAR3419 after the last administered dose was about 8 days, consistent with 
observations of plasma accumulation of SAR3419 on the weekly schedule [90,91]. A second cohort of patients $(n=25)$ was enrolled, utilizing a modified schedule consisting of four weekly doses of $55 \mathrm{mg} \mathrm{m}^{-2}$ followed by four bi-weekly doses based on pharmacokinetic simulations and pharmacodynamic observations, to evaluate an approach to reduce even further the incidence of the reversible corneal toxicity $[90,91]$. Preliminary reports suggest this approach was successful. The signals of clinical efficacy were maintained with a $28 \%$ ORR (seven of 25 patients), $33 \%$ in heavily pre-treated DLBCL patients (three of nine patients on the study), yet only one reversible grade 1 corneal event was noted in the 25 patients [91]. The sponsor has initiated three phase II trials since September 2011, one in ALL and two in DLBCL. One of the latter studies is a combination trial with rituximab (http://clinicaltrials.gov).

$A D C$ s in early Phase I clinical development utilizing potent tubulin-acting agents Besides the two compounds described above, there are thirteen other auristatin conjugates that are in early phase I clinical trials (Table 1). SGN75 , a conjugate of a humanized anti-CD70 monoclonal antibody with mcMMAF is currently in a phase I clinical trial for relapsed or refractory non-Hodgkin lymphoma or metastatic renal cell carcinoma $[92,93]$. The linker is uncleavable and the cytotoxic metabolite released within cancer cells is the cytotoxin-linker-cysteine moiety, the cysteine being the amino acid residue of the antibody to which the auristatin was attached $[13,29,92]$. Preliminary efficacy signals reported include a PR in a Mantle cell lymphoma patient among $16 \mathrm{NHL}$ patients on study, and two PRs out of 21 evaluable renal cell cancer patients on study (86, and sponsor web site), an encouraging signal of activity early in a phase I study. The MTD was $3 \mathrm{mg} \mathrm{kg}^{-1}$ given every 3 weeks and the terminal half-life was estimated to be 6 to 10 days. Adverse events $\geq$ grade 3 that were seen in $>2$ patients included thrombocytopenia, dyspnoea and fatigue, while the most common adverse events (any grade) were fatigue $(23 \%)$, nausea $(30 \%)$, dry eye $(23 \%)$ and thrombocytopenia (23\%) among the 41 patients treated [93]. A conjugate of a fully human anti-prostate specific membrane antigen (PSMA) monoclonal antibody with MMAE [94] is in a phase I trial in patients with taxane refractory, metastatic, castration resistant prostate cancer [95]. A preliminary report about the phase I trial described cohorts of patients (40 total subjects) who received doses of $0.4 \mathrm{mg} \mathrm{kg}^{-1}$ to $2.8 \mathrm{mg} \mathrm{kg}^{-1}$ [95]. While the MTD was not reached, and dose escalation continues, there were early suggestions of antitumour activity as reflected in declines in serum prostate specific antigen levels. Preliminary phase I clinical results were also reported for two other auristatinADCs, AGS-16M8F, an antiENPP3 antibody conjugated with mCMMAF [96] and ASG-5ME, and anti-SLC44A4 antibody conjugated with vcMMAE [97].

There are also six more ADCs in clinical evaluation utilizing the maytansinoid 'payload', besides the three com- pounds in phase II and III trials described above (Table 1). BT-062 is an anti-CD138 chimeric IgG4 antibody conjugated to the maytansinoid DM4 through reaction with the cleavable SPDB linker to form a highly hindered disulfide bond with the DM4 $[98,99]$. A phase I trial resulted in determining an MTD of $160 \mathrm{mg} \mathrm{m}^{-2}\left(\sim 4.3 \mathrm{mg} \mathrm{kg}^{-1}\right)$ when dosing once every 3 weeks in MM patients [100]. Among 13 evaluable patients treated at the MTD from among 32 total patients in the trial, there was one PR, one objective minor response of at least 1.5 years duration and five patients with stable disease for at least 105 days, for an overall CBR of about $50 \%$. Adverse event signals relating to the expression of CD138 on epithelial tissues were noted, especially at the maximum administered dose of $200 \mathrm{mg} \mathrm{m}^{-2}$, and included mucositis, stomatitis and hand/ foot syndrome. Adverse events at the MTD were generally mild to moderate and the safety profile was considered favourable [100, 101]. A phase I/lla study was recently initiated to characterize further tolerability and anti-MM activity in a more frequent dosing regimen, dosing weekly for 3 weeks on a 4 week cycle (http://clinicaltrials.gov). Thus far, BT062 is well tolerated up to $120 \mathrm{mg} \mathrm{m}^{-2}$ on this schedule [101]. Other maytansinoid ADCs that are in early phase I clinical evaluation, and which utilize the SPDB linker for conjugation of DM4, include SAR566658, a conjugate with the anti-CA6 antigen, a tumour-associated glycotope of Muc- 1 that is expressed on ovarian, breast, cervical, lung and pancreatic cancers [102], and BAY 94-9343, a conjugate of an anti-mesothelin antibody that targets mesothelioma, ovarian and pancreatic cancers [103]. In early 2012, phase I evaluation of IMGN529, an antiCD37 humanized IgG1 antibody conjugated to DM1 via the uncleavable SMCC linker [104, 105], was initiated in patients with $\mathrm{NHL}$, and recently, a phase I trial was begun with IMGN853, an anti-FOLR1 humanized IgG1 antibody conjugated to DM4 using a novel hydrophilic disulfide linker $[106,107]$.

In the next 12-24 months, with many ADCs in early phase I clinical trials (see Table 1), there will likely be a wealth of new clinical results which will provide valuable insights into the design of the next generation of ADCs. For example, the field may learn what targets make good targets for ADCs made with potent tubulin-acting agents, and understand what are the best linker-payload designs for an optimal ADC directed to certain targets or for certain indications. However, some general safety trends may already be noted from the clinical development so far reported. ADCs to two unrelated targets made with vcMMAE show neutropenia as a DLT at doses near $2 \mathrm{mg} \mathrm{kg}^{-1}$ given once every 3 weeks [30,59], while maytansinoid ADCs made with a variety of linker formats generally show little or no clinically significant myelosuppression [11]. ADCs made with uncleavable links with both the auristatin and maytansinoid payloads, where the active metabolite is a payload-linker-amino acid moiety [31,33], may show thrombocytopenia as a side effect which may 
be dose-limiting $[45,93,96,108,109]$. This side effect has not been clinically significant with ADC designs that release final active metabolites that lack hydrophilic charges groups that may be more readily effluxed from cells. One can expect that as more clinical information for more of the compounds listed in Table 1 becomes available, oncologists will learn how best to design and develop $A D C s$ to maximize the impact of these agents in treating disease.

\section{Conclusions}

With the recent approval in 2011 of brentuximab vedotin (Adcetris ${ }^{\circledR}$ ), and the extensive phase III programme being undertaken to develop trastuzumab emtansine which led to an application for marketing approval by the sponsor in August, 2012, it has become apparent that ADC technologies utilizing highly potent tubulin-acting agents are able to generate highly active, well-tolerated, anticancer agents that fulfill the long-awaited promise of the field. Active compounds can be generated against targets expressed on haematologic tumours (for example, brentuximab vedotin and SAR3419) as well as against targets expressed on solid tumours (for example, trastuzumab emtansine, lorvotuzumab mertansine), and they can be generated from antibodies such as trastuzumab that have some intrinsic antitumour activity, as well as from antibodies such as brentuximab and lorvotuzumab that have demonstrated no preclinical or clinical activity as 'naked' antibodies. The clinical experience gained over the last decade also suggests that these ADCs, conjugates of cytotoxic payloads to human/humanized antibodies, are generally not more immunogenic than 'naked' human/humanized antibodies in cancer patients.

Of the ADCs that target a solid tumour, trastuzumab emtansine has been the compound that has advanced most rapidly, from first-in-human dosing to phase III clinical trials in about 4 years $[9,54]$. Its development was greatly aided by the fact that so much was already known about the HER2 target, in particular with regard to patient selection, thanks to the prior development of trastuzumab itself. For other ADCs to novel targets, such knowledge will need to be developed during clinical trials, as for example, in the evaluation of antitumour activity of glembatumumab vedotin in breast cancer patients confirmed to express GPNMB on their tumour [60]. Development of a companion diagnostic test similar in nature to the immunohistochemical test for HER2 on breast cancer biopsies is likely essential for development of an ADC to a heterogeneous target such as GPNMB.

It is exciting to report that, after nearly 30 years of research, the emerging clinical data with several compounds suggest that ADCs promise to make a real difference to the lives of patients with cancer. As more compounds advance, one can envisage a future where patients are treated with active anti-tumour agents, among them ADCs, that lack the severe toxicities associated with chemotherapy.

\section{Competing Interests}

The author has completed the Unified Competing Interest form at http://www.icmje.org/coi_disclosure.pdf (available on request from the corresponding author) and declares JML had support from ImmunoGen, Inc., the company that developed the maytansinoid-ADC technology, for the submitted work, written as part of his duties as an employee of ImmunoGen, Inc., JML has been an employee of ImmunoGen, Inc. since 1987 to present and several compounds utilizing ImmunoGen's technology are described in this manuscript and JML has no other relationships or activities that could appear to have influenced the submitted work.

\section{REFERENCES}

1 Kohler G, Milstein C. Continuous cultures of fused cells secreting antibody of predefined specificity. Nature 1975; 256: 495-7.

2 Ross JS, Schenkein DP, Pietrusko R, Rolfe M, Linette GP, Stec J, Stagliano NE, Ginsburg GS, Symmans WF, Pusztai L, Hortobagyi GN. Targeted therapies for cancer. Am J Clin Pathol 2004; 122: 598-609.

3 McLaughlin P, Grillo-Lopez AJ, Link BK, Levy R, Czuczman MS, Williams ME, Heyman MR, Bence-Bruckler I, White CA, Cabanillas F, Jain V, Ho AD, Lister J, Wey K, Shen D, Dallaire BK. Rituximab chimeric anti-CD20 monoclonal antibody therapy for relapsed indolent lymphoma: half of the patients respond to a four-dose treatment program. J Clin Oncol 1998; 16: 2825-33.

4 Pulte D, Gondos A, Brenner H. On-going improvement in outcomes for patients diagnosed as having non-Hodgkin's lymphoma from 1990s to the 21 st century. Arch Intern Med 2008; 168: 469-76.

5 Dimitrov DS, Marks JD. Therapeutic antibodies: current state and future trends - is a paradigm change coming soon? In: Therapeutic Antibodies: Methods and Protocols, Vol. 525, ed. Dimitrov AS. Berlin: Humana Press, Springer, 2009; 1-27.

6 Weiner LM, Dhodapkar MV, Ferrone S. Monoclonal antibodies for cancer immunotherapy. Lancet 2009; 373: 1033-40.

7 Glennie MJ, van de Winkel JGJ. Renaissance of cancer therapeutic antibodies. Drug Discov Today 2003; 8: 503-10.

8 Chari RVJ. Targeted delivery of chemotherapeutics: tumor-activated prodrug therapy. Adv Drug Deliv Rev 1998; 31: 89-105.

9 Lambert JM. Drug-conjugated monoclonal antibodies for the treatment of cancer. Curr Opin Pharmacol 2005; 5: 543-9. 
10 Blättler WA, Chari RVJ. Drugs to enhance the therapeutic potency of anticancer antibodies: antibody-drug conjugates as tumor-activated prodrugs; Chapter 19. In: Anticancer Agents: Frontiers in Cancer Chemotherapy, Vol. 796, eds Ojima I, Vite GD, Altmann K-H. Washington, DC: ACS Symposium Series, 2001; 317-38.

11 Lambert JM. Antibody-maytansinoid conjugates: a new strategy for the treatment of cancer. Drugs Future 2010; 35: 471-80.

12 Vater CA, Goldmacher VS. Antibody-cytotoxic compound conjugates for oncology. In: Macromolecular Anticancer Therapeutics, Cancer Drug Discovery and Development 2010, Part 4, eds Reddy LH, Couvreur P. Berlin: Springer, 2010; 331-69.

13 Carter PJ, Senter PD. Antibody-drug conjugates for cancer therapy. Cancer J 2008; 14: 154-69.

14 Smith AL, Nicolaou KC. The enediyne antibiotics. J Med Chem 1996; 39: 2103-17.

15 Ricart AD. Antibody drug conjugates of calicheamicin derivative: gemtuzumab ozogamicin and inotuzumab ozogamicin. Clin Cancer Res 2011; 17: 6417-27.

16 Bross PF, Beitz J, Chen G, Chen XH, Duffy E, Kieffer L, Roy S, Sridhara R, Rahman A, Williams G, Pazdur R. Approval summary: gemtuzumab ozogamicin in relapsed acute myeloid leukemia. Clin Cancer Res 2001; 7: 1490-6.

17 Sievers EL, Larson RA, Stadtmauer EA, Estey E, Lowenberg B, Dombret $\mathrm{H}$, Karanes $\mathrm{C}$, Theobald M, Bennett JM, Sherman ML, Berger MS, Eten CB, Loken MR, van Dongen JJ, Bernstein ID, Appelbaum FR. Efficacy and safety of gemtuzumab ozogamicin in patients with CD33-positive acute myeloid leukemia in first relapse. J Clin Oncol 2001; 19: 3244-54.

18 Petersdorf S, Kopecky K, Stuart RK, Larson RA, Nevill TJ, Stenke L, Slovak ML, Tallman MS, Willman CL, Erba H, Appelbaum FR. Preliminary results of Southwest Oncology Group Study SO106: an international intergroup phase 3 randomized trial comparing the addition of gemtuzumab ozogamicin to standard induction therapy versus standard induction therapy followed by a second randomized to post-consolidation gemtuzumab ozogamicin versus no additional therapy for previously untreated acute myeloid leukemia. Blood 2009; 114: 326. abstr 790.

19 Ravandi F. Gemtuzumab ozogamicin: one size does not fit all - the case for personalized therapy. J Clin Oncol 2011; 29: 349-51.

20 Burnett AK, Hills RK, Milligan D, Kjeldsen L, Kell J, Russell NH, Yin JAL, Hunter A, Goldstone AH, Wheatley K. Identification of patients with acute myeloblastic leukemia who benefit from the addition of gemtuzumab ozogamicin: results of the MRC AML15 trial. J Clin Oncol 2011;29:369-77.

21 Castaigne S, Pautas C, Terre C, Raffoux E, Bordessoule D, Bastie J-N, Legrand O, Thomas X, Turlure P, Reman O, de Revel T, Gastaud L, de Gunzburg N, Contentin N, Henry E, Marolleau J-P, Aljijakli NA, Rousselot P, Fenaux P, Preudhomme C, Chevret S, Dombret H. Effect of gemtuzumab ozogamicin on survival of adult patients with de novo acute myeloid leukemia (ALFA-0701): a randomized, open-label, phase 3 study. Lancet 2012; 379: 1508-16.

22 Advani A, Coiffier B, Czuczman MS, Dreyling M, Foran J, Gine E, Gisselbrecht C, Ketterer N, Nasta S, Rohatiner A, Schmidt-Wolf IGH, Schuler M, Sierra J, Smith MR, Verhoef G, Winter JN, Boni J, Vandenries E, Shapiro M, Fayad L. Safety, pharmacokinetics, and preliminary clinical activity of inotuzumab ozogamicin, a novel immunoconjugate for the treatment of B-Cell non-Hodgkin's lymphoma: results of a phase I study. J Clin Oncol 2010; 28: 2085-93.

23 Giles FJ, Kantarjian HM, Kornblau SM, Thomas DA, Garcia-Moreno G, Waddelow TA, David CL, Phan AT, Colburn $\mathrm{DE}$, Rashid A, Estey EH. Mylotarg [gemtuzumab ozogamicin] therapy is associated with hepatic venoocclusive disease in patients who have not received stem cell transplantation. Cancer 2001; 92: 406-13.

24 Wadleigh M, Richardson PG, Zahrieh D, Lee SJ, Cutler C, Ho V, Alyea EP, Antin JH, Stone RM, Soiffer RJ, DeAngelo DJ. Prior gemtuzumab ozogamicin exposure significantly increases the risk of veno-occlusive disease in patients who undergo myeloablative allogeneic stem cell transplantation. Blood 2003; 102: 1578-82.

25 Kantarjian $H$, Thomas D, Jorgensen J, Jabbour E, Kebriaei P, Rytting M, York S, Ravavdi F, Kwari M, Faderl S, Rios MB, Cortes J, Fayad L, Tarnai R, Wang SA, Champlin R, Advani A, O'Brien S. Inotuzumab ozogamicin, an anti-CD22-calicheamicin conjugate, for refractory and relapsed acute lymphocytic leukaemia: a phase 2 study. Lancet Oncol 2012; 13:403-11.

26 Terrett JA, Gangwar S, Rao-Naik C, Pan C, Guerlavais V, Huber M, Chong C, Green L, Cardarelli P, King D, Deshpande S, Rangan V, Coccia M, Lu L, Passmore D, Blansett D, Dai R, Sufi B, Zhang Q, Chen L, Soderberg C, Kwok E, Horgan K, Cortez O, Sattari P. Single, low dose treatment of lymphoma and renal cancer xenografts with human anti-CD70 antibody-toxin conjugates, results in long term cures. Proc Am Assoc Cancer Res 2007; 48: abstr 4112.

27 Sapra P, Stein R, Pickett J, Qu Z, Govindan SV, Cardillo TM, Hansen HJ, Horak ID, Griffiths GL, Goldenberg DM. Anti-CD74 antibody-doxorubicin conjugate IMMU-110, in a human multiple myeloma xenograft and in monkeys. Clin Cancer Res 2005; 11: 5257-64.

28 Dumontet C, Jordan MA. Microtubule-binding agents: a dynamic field of cancer therapeutics. Nat Rev Drug Discov 2010; 9: 790-803.

29 Lyon RP, Meyer DL, Setter JR, Senter PD. Conjugation of anticancer drugs through endogenous monoclonal antibody cysteine residues. Methods Enzymol 2012; 502: 123-38.

30 Senter PD, Sievers EL. The discovery and development of brentuximab vedotin for use in relapsed Hodgkin lymphoma and systemic anaplastic large cell lymphoma. Nat Biotechnol 2012; 30:631-7.

31 Goldmacher VS, Chittenden T, Chari RVJ, Kovtun YV, Lambert JM. Antibody-drug conjugates for targeted cancer therapy. Annu Rep Med Chem 2012; 47: 349-66. 
32 Wang L, Amphlett G, Blättler WA, Lambert JM, Zhang W. Structural characterization of the maytansinoid-monoclonal antibody immunoconjugate, huN901-DM1, by mass spectrometry. Protein Sci 2005; 14 : 2436-46.

33 Erickson HK, Lambert JM. ADME of antibody-maytansinoid conjugates. AAPS J 2012; 14: 799-805.

34 Erickson HK, Lewis Phillips GD, Leipold DD, Provenzano CA, Mai E, Johnson HA, Gunter B, Audette CA, Gupta M, Pinkas $J$, Tibbitts J. The effect of different linkers on target cell catabolism and pharmacokinetics/pharmacodynamics of trastuzumab maytansinoid conjugates. Mol Cancer Ther 2012; 11: 1133-42.

35 Kellogg BA, Garrett L, Kovtun Y, Lai KC, Leece B, Miller M, Payne G, Steeves R, Whiteman KR, Widdison W, Xie H, Singh R, Chari RVJ, Lambert JM, Lutz RJ. Disulfide-linked antibody-maytansinoid conjugates: optimization of in vivo activity by varying the steric hindrance at carbon atoms adjacent to the disulfide linkage. Bioconjug Chem 2011;21: 84-92.

36 Francisco JA, Cerveny CG, Meyer DL, Mixan BJ, Klussman K, Chace DF, Rejniak SX, Gordon KA, DeBlanc R, Toki BE, Law C-L, Doronina SO, Siegall CB, Senter PD, Wahl AF. CAC10-vcMMAE, an anti-CD30-monomethyl auristatin E conjugate with potent and selective antitumor activity. Blood 2003; 102: 1458-65.

37 Younes A, Gopal AK, Smith SE, Ansell SM, Rosenblatt JD, Savage KJ, Ramchandren R, Bartlett NL, Cheson BD, de Vos S, Forero-Torres A, Moskowitz CH, Connors JM, Engert A, Larsen EK, Kennedy DA, Sievers EL, Chen R. Results of a pivotal phase II study of brentuximab vedotin for patients with relapsed or refractory Hodkgin's lymphoma. J Clin Oncol 2012; 30: 2183-89.

38 Pro B, Advani R, Brice P, Bartlett NL, Rosenblatt JD, Illidge T, Matous J, Ramchandren R, Fanale M, Connors JM, Yang Y, Sievers EL, Kennedy DA, Shustov A. Brentuximab vedotin (SGN-35) in patients with relapsed or refractory systemic anaplastic lage-cell lymphoma: results of a phase II trial. J Clin Oncol 2012; 30: 2190-6.

39 Younes A, Bartlett NL, Leonard JP, Kennedy DA, Lynch CM, Sievers EL, Forero-Torres A. Brentuximab vedotin (SGN-35) for relapsed CD30-positive lymphomas. N Engl J Med 2010; 363: 1812-21.

40 Fanale MA, Forero-Torres A, Rosenblatt JD, Advani RH, Franklin AR, Kennedy DA, Han TH, Sievers EL, Bartlett NL. A phase I weekly dosing study of brentuximab vedotin in patients with relapsed/refractory CD30-positive hematologic malignancies. Clin Cancer Res 2012; 18: 248-55.

41 Advani R, Oki Y, Shustov A, Grove LE, Bartlett NL. Brentuximan vedotin for relapsed or refractory non-Hodgkin lymphoma: preliminary results from a phase 2 study. J Clin Oncol 2012; 30: (Suppl.): abstr 8070.

42 Lewis Phillips GD, Li G, Dugger D, Crocker LM, Parsons KL, Mai E, Blättler WA, Lambert JM, Chari RJ, Lutz RJ, Wong WLT, Jacobson FS, Koeppen H, Schwall RH, Kenkare-Mitra SR, Spenser SD, Sliwkowski MX. Targeting HER2-positive breast cancer with trastuzumab-DM1, and antibody-cytotoxic drug conjugate. Cancer Res 2008; 68: 9280-90.

43 Erickson HK, Widdison WC, Mayo MF, Whiteman K, Audette C, Wilhelm SD, Singh R. Tumor delivery and in vivo processing of disulfide-linked and thioether-linked antibody-maytansinoid conjugates. Bioconjug Chem 2010; 21: 84-92.

44 Shen B-Q, Bumbaca D, Saad O, Yue Q, Pastuskoas CV, Khojasteh SC, Tibbits J, Kaur S, Wang B, Chu Y-W, LoRusso PM, Girish S. Catabolic fate and pharmacokinetic characterization of trastuzumab emtansine: an emphasis on preclinical and clinical catabolism. Curr Drug Metab 2012; 13: 901-10.

45 Krop IE, Beeram M, Modi S, Jones SF, Holden SN, Yu W, Girish S, Tibbetts J, Yi J-H, Sliwkowski MX, Jacobson F, Lutzker SG, Burris HA. Phase I study of trasuzumab-DM1, an HER2 antibody-drug conjugate, given every 3 weeks to patients with HER2-positive metastatic breast cancer. J Clin Oncol 2010; 28: 2698-704.

46 Beeram M, Krop IE, Burris HA, Girish S, Yu W, Lu MW, Holden SN, Modi S. A phase 1 study of weekly dosing of trastuzumab emtansine (T-DM1) in patients with advanced human epidermal growth factor 2-positive breast cancer. Cancer 2012; 118: 5733-40.

47 Burris HA III, Rugo HS, Vukelja SJ, Vogel CL, Borson RA, Limentani S, Tan-Chiu E, Krop IE, Michaelson RA, Girish S, Amler L, Zheng M, Chu Y-W, Klencke B, O'Shaughnessy JA. Phase II study of the antibody drug conjugate trastuzumab-DM1 for the treatment of human epidermal growth factor receptor 2 (HER2)-positive breast cancer after prior HER2-directed therapy. J Clin Oncol 2011; 29: 398-405.

48 Krop I, LoRusso P, Miller KD, Modi S, Yardley D, Rodriguez G, Lu M, Burington B, Agresta S, Rugo H. A phase 2 study of the HER2 antibody-drug conjugate trastuzumab-DM1 (T-DM1) in patients (pts) with HER2-positive metastatic breast cancer (MBC) previously treated with trastuzumab, lapatinib, and chemotherapy. Ann Oncol 2010; 21: (Suppl. 8): viii97. abstr 277.

49 Girish S, Gupta M, Wang B, Lu D, Krop IE, Vogel CL, Burris HA III, LoRusso PM, Yi J-H, Saad O, Tong B, Chu Y-W, Holden S, Joshi A. Clinical pharmacology of trastuzumab emtansine (T-DM1): an antibody-drug conjugate in development for the treatment of HER2-positive cancer. Cancer Chemother Pharmacol 2012; 69: 1229-40.

50 Dijkers EC, Oude Munnink TH, Kosterink JG, Brouwers AH, Jager PL, de Jong JR, van Dongen GA, Schröder CP, Lub-de Hooge MN, de Vries EG. Biodistribution of 89Zr-trastuzumab and PET imaging of HER2-positive lesions in patients with metastatic breast cancer. Clin Pharmacol Ther 2010; 87: 586-92.

51 Fishkin N, Maloney EK, Chari RV, Singh R. A novel pathway for maytansinoid release from thioether linked antibody-drug conjugates (ADCs) under oxidative conditions. Chem Commun (Camb) 2011; 47: 10752-4.

52 Hurvitz S, Dirix L, Kocsis J, Gianni L, Lu J, Vinholes J, Song C, Tong B, Chu YW, Perez EA. Trastuzumab emtansine (T-DM1) 
vs. trastuzumab plus docetaxel $(\mathrm{H}+\mathrm{T})$ in previously-untreated HER2-positive metastatic breast cancer (MBC): primary results of a randomized, multicenter, open-label Phase II study (TDM4450g/BO21976). Eur J Cancer 2011; 47: S330. abstr 5001.

53 Dang CT, Gianni L, Romieu G, Dirix L, Campone M, Citron ML, Zamagni C, Krop IE, Xu N, Smitt M, Suter T. Cardiac safety in a phase II study of trasuzumab emtansine (T-DM1) following anthracycline-based chemotherapy as adjuvant or neoadjuvant therapy for early-stage HER2-positive breast cancer. J Clin Oncol 2012; 30: (Suppl.): abstr 532.

54 Verma S, Miles D, Gianni L, Krop IE, Welslau M, Baselga J, Pegram MD, Oh D-Y, Dieras V, Guardino E, Fang L, Lu MW, Olsen SR, Blackwell K. Trastuzumab emtansine for HER2-positive advanced breast cancer. N Engl J Med 2012; 367: 1783-91.

55 Yamashita-Kashima Y, Shu S, Harada N, Fujimoto-Ouchi K. Potentiation of trastuzumab emtansine (T-DM1)-driven antitumor activity by pertuzumab in a HER2-positive gastric cancer model. J Clin Oncol 2012; 30: (Suppl.): abstr e13502.

56 Hurvitz SA, Kakkar R. The potential for trastuzumab emtansine in human epidermal growth factor receptor 2 positive metastatic breast cancer: latest evidence and ongoing studies. Ther Adv Med Oncol 2012; 4: 235-45.

57 Tse KF, Jeffers M, Pollack VA, McCabe DA, Shadish ML, Khramtsov NV, Hackett CS, Shenoy SG, Kuang B, Boldog FL, MacDougall JR, Rastelli L, Herrmann J, Gallo M, Gazit-Bornstein G, Senter PD, Meyer DL, Lichenstein HS, LaRochelle WJ. CR011, a fully human monoclonal antibody-auristatin E conjugate, for the treatment of melanoma. Clin Cancer Res 2006; 12: 1373-82.

58 Rose AAN, Grosset A-A, Dong Z, Russo C, MacDonald PA, Bertos NR, St-Pierre Y, Simantov R, Hallett M, Park M, Gaboury L, Siegel PM. Glycoprotein Nonmetastatic B is an independent prognostic indicator of recurrence and a novel therapeutic target in breast cancer. Clin Cancer Res 2010; 16: 2147-56.

59 Hamid O, Sznol M, Pavlick AC, Kluger HM, Kim KB, Boasberg PD, Simantov R, Davis TA, Crowley E, Hawthorne T, Green J, Hwu P. Frequent dosing and GPNMB expression with CDX-011 (CR011-vcMMAE), an antibody-drug conjugate (ADC), in patients with advanced melanoma. J Clin Oncol 2010; 28: (Suppl.): abstr 8525.

60 Saleh M, Bendell J, Rose A, Siegel PM, Hart L, Sirpal S, Jones S, Crowley E, Simantov R, Vahdat L. Correlation of GPNMB expression with outcome in breast cancer $(B C)$ patients treated with the antibody-drug conjugate (ADC), CDX-011 (CR011-vcMMAE). J Clin Oncol 2010; 28: (Suppl.): abstr 1095.

61 Griffin JD, Hercend T, Beveridge R, Schlossman SF. Characterization of an antigen expressed by human natural killer cells. J Immunol 1983; 130: 2947-51.

62 Roguska MA, Pedersen JT, Henry AH, Searle SMJ, Roja CM, Avery B, Hoffee M, Cook S, Lambert JM, Blättler WA, Rees AR, Guild BC. A comparison of two murine monoclonal antibodies humanized by CDR-grafting and variable domain resurfacing. Protein Eng 1996; 9: 895-904. (Erratum: Protein Eng 1997; 10: 181).
63 Lanier LL, Chang C, Azuma M, Ruitenberg JJ, Hemperly JJ, Phillips JH. Molecular and functional analysis of human natural killer cell-associated neural cell adhesion molecule (N-CAM/CD56). J Immunol 1991; 146: 4421-6.

64 Tassone P, Gozzini A, Goldmacher V, Shammas MA, Whiteman KR, Carrasco DR, Li C, Allam CK, Venuta S, Anderson KC, Munshi NC. In vitro and in vivo activity of the maytansinoid immunoconjugate

huN901-N2'-deacetyl-N2'-(3-mercapto-1-oxopropyl)-maytansine against CD56+ multiple myeloma cells. Cancer Res 2004; 64: 4629-36.

65 Jensen M, Berthold F. Targeting the neural cell adhesion molecule in cancer. Cancer Lett 2007; 258: 9-21.

66 Roy DC, Ouellet S, Le Houillier C, Ariniello PD, Perreault C, Lambert JM. Elimination of neuroblastoma and small cell lung cancer cells with an anti-neural cell adhesion molecule immunotoxin. J Natl Cancer Inst 1996; 88: 1136-45.

67 Whiteman KR, Murphy MF, Cohane KP, Sun W, Carrigan CN, Mayo MF, Li Y, Lutz RJ. Preclinical evaluation of IMGN901 (huN901-DM1) as a potential therapeutic for ovarian cancer. Proc Am Assoc Cancer Res 2008; 49: abstr 2135.

68 Chari RVJ, Xie H, Steeves RM, Lambert JM. Additive and synergistic effects of combination treatment with huN901-DM1 (BB-10901) and chemotherapeutic agents in small cell lung cancer xenograft tumor models.

Proceedings of AACR-NCI-EORTC International Conference: Molecular Targets and Cancer Therapeutics. 2005; 70, abstr A58.

69 Woll P, Fossella FV, O'Brien MO, Clinch Y, Donaldson K, O'Keeffe J, Zildjian S, Fram R, Qin A, Lorigan P. Phase I study of IMGN901 (BB-10901) in patients with CD56-positive solid tumors. Eur J Cancer 2008; 6: (Suppl.): abstr 510.

70 Woll PJ, O'Brien M, Fossella F, Shah M, Clinch Y, O'Keeffe J, Qin A, O'Leary J, Lorigan P. Phase I study of lorvotuzumab mertansine (IMGN901) in patients with CD56-positive solid tumors. Ann Oncol 2010; 21: (Suppl. 8): abstr 536P.

71 Chanan-Khan A, Wolf J, Garcia J, Gharibo M, Jagannath S, Manfredi D, Sher T, Martin C, Zildjian SH, O'Leary J, Vescio R. Efficacy analysis from a phase I study of lorvotuzumab mertansine (IMGN901) used as monotherapy in patients with heavily pre-treated CD56-positive multiple myeloma. Blood 2010; 116: 819. Abstr 1962.

72 Tolcher AW, Forouzesh B, McCreery H, Hammond L, Patnaik A, Lambert J, Xie H, Hoffee M, Zentgraf R, Zinner R, Glisson B, Clinch Y, Barrington P, Rowinsky E, Fossella F. A phase I and pharmacokinetic study of BB-10901, a maytansinoid immunoconjugate, in CD56 expressing tumors. Eur J Cancer 2002; 38: (Suppl. 7): S152-3. Abstr 509.

73 McCann J, Fossella FV, Villalona-Calero MA, Tolcher AW, Fidias P, Raju R, Zildjian S, Giuld R, Fram R. Phase II trial of huN901-DM1 in patients with relapsed small cell lung cancer (SCLC) and CD56-positive small cell carcinoma. J Clin Oncol 2007; 25: (18S): Abstr 18084.

74 Fossella F, Woll PJ, Lorigan P, Tolcher A, O'Brien M, O'Keeffe J, Zildjian S, Qin A, O'Leary J, Villalona-Calero M. Clinical 
experience of IMGN901 (BB-10901) in patients with small cell lung carcinoma. J Thorac Oncol [13th World Conference on Lung Cancer, 2009] 2009; 4(Suppl. 9), Abstr 6327.

(PD4.3.5).

75 Berdeja JG, Ailawadhi S, Weitman SD, Zildjian S, O'Leary JJ, O'Keeffe J, Guild R, Whiteman K, Sher T, Chanan-Khan A. Phase I study of lorvotuzumab mertansine (LM, IMGN901) in combination with lenalidomide (Len) and dexamethasone (Dex) in patients with CD56-positive relapsed or relapsed/refractory multiple myeloma (MM). J Clin Oncol 2011; 29: (Suppl.): abstr 8013.

76 Allen PJ, Bowne WB, Jaques DP, Brennan MF, Busam K, Coit DG. Merkel cell carcinoma: prognosis and treatment of patients from a single institution. J Clin Oncol 2005; 23: 2300-09.

77 Carrigan CN, Xu S, Zhao Y, Testa N, Gabriel R, O'Keefe J, Qin A, O'Leary J, Payne G, Lutz RJ. The antigen target of lorvotuzumab mertansine (IMGN901), CD56, is expressed at significant levels in Merkel cell carcinoma (MCC). Proc Am Assoc Cancer Res 2010; 51: abstr 5335.

78 Whiteman KR, Ab O, Bartle LM, Foley K, Goldmacher VS, Lutz RJ. Efficacy of IMGN901 (huN901-DM1) in combination with bortezomib and lenalidomide against multiple myeloma cells in preclinical studies. Proc Am Assoc Cancer Res 2008; 49: abstr 2146.

79 Whiteman KR, Johnson HA, Xu S, Pinkas J, Lutz RJ. Lorvotuzumab mertansine (IMGN901) in combination with standard-of-care paclitaxel/carboplatin therapy is highly active in a preclinical xenograft model of ovarian cancer. Proc Am Assoc Cancer Res 2011; 52: abstr 1781.

80 Whiteman KR, Johnson H, Xu S, Moreland J, Vyas V, Bartle LM, Ab O, Carrigan C, Pinkas J, Lutz RJ. Combination therapy with IMGN901 and lenalidomide plus low-dose dexamethasone is highly effective in multiple myeloma xenograft models. Proc Am Assoc Cancer Res 2009; 50: abstr 2799.

81 Berdeja JG, Ailawadhi MD, Niesvizky R, Wolf JL, Zildjian SH, O'Leary J, Chanan-Khan A. Phase I study of lorvotuzumab mertansine (IMGN901) in combination with lenalidomide and dexamethasone in patients with CD56-positive relapsed or relapsed/refractory multiple myeloma - a preliminary safety and efficacy analysis of the combination. Blood 2010; 116: abstr 1934.

82 Spigel DR, Bendell J, Mita AC, Argiris A, Kurkjian C, Hann CL, Segota Z, Guild R, Mastico R, Gutierrez ME. Phase I/II study to assess the safety, pharmacokinetics (PK) and efficacy of lorvotuzumab mertansine (LM, IMGN901) in combination with carboplatin/etoposide in patients with solid tumors including small-cell lung cancer (SCLC). 37th ESMO Congress, Vienna. Ann Oncol 2012; 23: (Suppl. 9): Abstr 1543TiP.

83 Nadler LM, Anderson KC, Marti G, Bates M, Park E, Daley JF, Schlossman SF. B4, a human B lymphocyte-associated antigen expressed on normal, mitogen activated, and malignant B lymphocytes. J Immunol 1983; 131: 244-50.

84 Roguska MA, Pedersen JT, Keddy CA, Henry AH, Searle SJ, Lambert JM, Goldmacher VS, Blättler WA, Rees AR, Guild BC.
Humanization of murine monoclonal antibodies through variable domain resurfacing. Proc Natl Acad Sci USA 1994; 91: 969-73.

85 Blanc V, Bousseau A, Caron A, Carrez C, Lutz RJ, Lambert JM. SAR3419: an anti-CD19-maytansinoid immunoconjugate for the treatment of B-cell malignancies. Clin Cancer Res 2011; 17:6448-58.

86 Lutz RJ, Zuany-Amorim C, Vrignaud P, Mayo MF, Guerif S, Xie H, Blanc V, Bissery MC, Hercend T. Preclinical evaluation of SAR3419 (huB4-DM4), an anti-CD19-maytansinoid immunoconjugate, for the treatment of B-cell lymphoma. Proc Am Assoc Cancer Res 2006; 47: abstr 3731.

87 Al Katib AM, Aboukameel A, Mohammad R, Bissery M-C, Zuany-Amorim C. Superior antitumor activity of SAR3419 to rituximab in xenograft models for non-Hodgkin's lymphoma. Clin Cancer Res 2009; 15: 4038-45.

88 Younes A, Gordon L, Kim S, Romaguera J, Copeland AR, de Castro Farial S, Kwak L, Fayad L, Hagemeister F, Fanale M, Lambert J, Bagulho T, Morariu-Zamfir R. Phase I multi-dose escalation study of the anti-CD19 maytansinoid immunoconjugate SAR3419 administered by intravenous (IV) infusion every 3 weeks to patients with relapsed/refractory B-cell non-Hodgkin's lymphoma (NHL). Blood 2009; 114: abstr 585.

89 Younes A, Kim S, Romaguera J, Copeland A, Farial SD, Kwak LW, Fayad L, Hagemeister F, Fanale M, Neelapu S, Lambert JM, Morariu-Zamfir R, Payrard S, Gordon LI. Phase I multidose-escalation study of the anti-CD19 maytansinoid immunoconjugate SAR3419 administered by intravenous infusion every 3 weeks to patients with relapsed/refractory B-cell lymphoma. J Clin Oncol 2012; 30: 2776-82.

90 Coiffier B, Ribrag V, Dupuis J, Tilly H, Haioun C, Morschhauser F, Lamy T, Brehar O, Houot R, Lambert J, Morariu-Zamfir R. Phase I/II study of the anti-CD19 maytansinoid immunoconjugate SAR3419 administered weekly to patients (pts) with relapsed/refractory B-cell non-Hodgkin lymphoma (NHL). J Clin Oncol 2011; 29: abstr 8017.

91 Coiffier B, Morschhauser F, Dupuis J, Haioun C, Laine F, Houot R, Tilly H, Brehar O, Lambert J, Fagniez N, Payrard S, Ribrag V. Phase I study cohort evaluating an optimized administration schedule of SAR3419, an anti-CD19 DM4-loaded antibody-drug conjugate (ADC), in patients (pts) with CD19 positive relapsed/refractory B-cell non-Hodgkin's lymphoma (NCT00796731). J Clin Oncol 2012; 30: abstr 8057.

92 Oflazoglu E, Stone IJ, Gordon K, Wood CG, Repasky EA, Grewal IS, Law CL, Gerber HP. Potent anticarcinoma activity of the humanized anti-CD70 antibody h1F6 conjugated to the tubulin inhibitor auristatin via an uncleavable linker. Clin Caner Res 2008; 14:6171-80.

93 Thompson JA, Forero-Torres A, Heath El, Ansell SM, Pal SK, Infante JR, de Vos S, Hamlin PA, Zhao B, Klussman K, Whiting NC. SGN75: the effect of SGN-75, a novel antibody-drug conjugate (ADC), in treatment of patients with renal cell carcinoma (RCC) or non-Hodgkin lymphoma (NHL): a phase I study. J Clin Oncol 2011; 29: (Suppl.): abstr 3071. 
94 Wang $X, M a D$, Olson WC, Heston WD. In vitro and in vivo responses of advanced prostate tumors to PSMA ADC, an auristatin-conjugated antibody to prostate-specific membrane antigen. Mol Cancer Ther 2011; 10: 1728-39.

95 Mega AE, Petrylak DP, Kantoff P, Stephenson J, Vogelzang NJ, Dreicer R, Shore ND, Stambler N, Carpenito J, D'Ambrosio P, Israel RJ. Prostate-specific membrane antigen antibody drug conjugate (PSMA ADC): a phase I trial in metastatic castration-resistant prostate cancer (mCPRC) previously treated with a taxane. J Clin Oncol 2012; 30: (Suppl.): abstr 4662.

96 Gudas JM, Torgo M, An Z, Jia XC, Morrison KJ, Morrison RK, Kanner SB, Raitano AB, Jakobovits A. AGS-16M8F: a novel antibody-drug conjugate (ADC) for treating renal and lier cancers. ASCO Genitourinary Cancers Symposium 2010. abstr 328.

97 Morris MJ, Bruce JY, Reyno LM, Anand B, Hartford A, Jelaca-Maxwell K, Lackey J, Eisenberger MA. Phase I trial of ASG-5ME in metastatic castration-resistant prostate cancer (CRPC). J Clin Oncol 2012; 30: (Suppl.): abstr 4568.

98 Tassone $P$, Goldmacher VS, Neri P, Gozzini A, Shammas MA, Whiteman KR, Hylander-Gans LL, Carrasco DR, Hideshima T, Shringarpure R, Shi J, Allam CK, Wijdenes J, Venuta S, Munshi NC, Anderson KC. Cytotoxic activity of the maytansinoid immunoconjugate B-B4-DM1 against CD138+ multiple myeloma cells. Blood 2004; 104: 3688-96.

99 Ikeda H, Hideshima T, Fulciniti M, Lutz RJ, Yasui H, Okawa Y, Lutz RJ, Yasui H, Okawa Y, Kiziltepe T, Vallet S, Pozzi S, Santo L, Perrone G, Tai YT, Cirstea D, Raje NS, Uherek C, Dälken B, Aigner S, Osterroth F, Munshi N, Richardson P, Anderson KC. The monoclonal antibody nBT062 conjugated to cytotoxic maytansinoids has selective cytotoxicity against CD138-positive multiple myeloma cells in vitro and in vivo. Clin Cancer Res 2009; 15: 4028-37.

100 Jagannath S, Chanan-Khan A, Heffner LT, Avigan D, Zimmerman TM, Lonial S, Lutz RJ, Engling A, Uherek C, Osterroth F, Ruehle M, Beelitz MA, Niemann G, Wartenberg-Demand A, Haeder T, Anderson KA, Munshi N. BT062, an antibody-drug conjugate directed against CD138, shows clinical activity in patients with relapsed or relapsed/refractory multiple myeloma. Blood 2011; 118: abstr 305.

101 Beck A, Lambert J, Sun M, Lin K. Fourth world antibody-drug conjugate summit. MAbs 2012; 4: 637-47.

102 Carrigan C, Zuany-Amorim C, Mayo M, Tavares DJ, Lutz RJ, Kellogg EA, Blanc V, Vrignaud P, Bissery M, Payne G.
Preclinical evaluation of SAR566658 (huDS6-DM4) in mice bearing human tumor xenografts of breast, ovarian, lung, cervical and pancreatic cancer. Eur J Cancer 2008; 6: 166. abstr 525.

103 Schatz CA, Golfier S, Scheider C, Kopitz C, Berhorster K, Henderson D, Schmitz A, Krahn T, Kreft B. Efficacy and candidate biomarker evaluation for the anti-mesothelin antibody drug conjugate (ADC) BAY 94-9343, mesothelin-ADC in mesothelin-positive preclinical xenograft models. Proc Am Assoc Cancer Res 2012; 72: (8 Suppl.): abstr 2726.

104 Park PU, Yi Y, Li M, Chicklas S, Lai KC, Mayo MF, Coccia JA, Deckert J, Pinkas J, Chittenden TD. Antibody and linker selection for the anti-CD37 antibody-maytansinoid conjugate IMGN529 for the treatment of B-cell malignancies. Proc Am Assoc Cancer Res 2011; 71: abstr 2830.

105 Deckert J, Mayo MF, Yi Y, Li M, Chicklas S, Tavares DJ, Pinkas J, Chittenden TD, Lutz RJ, Lambert JM, Park P. IMGN529: a therapeutic maytansinoid conjugate of an anti-CD37 antibody with multiple mechanisms of action for B-cell lymphoma and leukemia. Proc Am Assoc Cancer Res 2011; 71: abstr 4565.

106 Ab O, Bartle LM, Rui L, Coccia J, Johnson HA, Whiteman KR, Kellogg B, Clancy L, Sun X, Goldmacher VS. IMGN853, an anti-folate receptor I antibody-maytansinoid conjugate for targeted cancer therapy. Proc Am Assoc Cancer Res 2011; 71: abstr 4576.

107 Whiteman KR, Johnson HA, Xu S, Carrigan CN, Ab O, Pinkas J. Preclinical evaluation of IMGN853, an anti-FOLR1 antibody-maytansinoid conjugate, as a potential therapeutic for ovarian cancer. Proc Am Assoc Cancer Res 2011; 71: abstr 1760.

108 Thon JN, Devine MT, Jurak Begonja A, Tibbitts J, Italiano JE Jr. High-content live-cell imaging assay used to establish mechanism of trastuzumab emtansine (T-DM1)-mediated inhibition of platelet production. Blood 2012; 120: 1975-84.

109 Bender BC, Schaedeli-Stark F, Kock R, Joshi A, Chu YW, Rugo H, Krop IE, Girish S, Friberg LE, Gupta M. A population pharmacokinetic/pharmacodynamic model of thrombocytopenia characterizing the effect of trastuzumab emtansine (T-DM1) on platelet counts in patients with HER2-positive metastatic breast cancer. Cancer Chemother Pharmacol 2012; 70: 591-601. 